\title{
Influence of lactose intolerance and physical activity level on bone mineral density in young women
}

http://dx.doi.org/10.11606/1807-5509201700040787

\author{
Najoua Adriana SALOMÃO* \\ Amandio Aristides Rihan GERALDES ${ }^{* *}$ \\ Adriano Eduardo LIMA-SILVA*** \\ ${ }^{*}$ Curso de Educação \\ Física, Faculdade \\ Estácio de Alagoas, \\ Maceió, AL, Brasil. \\ ${ }^{* *}$ Centro de \\ Educação Física \\ Universidade Federal \\ de Alagoas, Maceió, \\ AL, Brasil. \\ ${ }^{* * *}$ Centro \\ Acadêmico de \\ Vitória, Universidade \\ Federal de \\ Pernambuco, Vitória \\ de Santo Antão, PE, \\ Brasil.
}

\begin{abstract}
The aim of this study was to verify the effect of physical activity level on bone mineral density (BMD) in pre-menopausal women with lactose intolerance. Sixty women was engaged in this study lage: $31.9 \pm 6.9$ years) and were initially separated into two groups: 30 women with lactose intolerance (LI) and 30 controls (C). The groups were further subdivided into less and more active using the median of weekly total energy expenditure, estimated by the International Physical Activity Questionnaire (IPAQ-long version). The $\mathrm{LI}$ diagnosis was confirmed by lactose intolerance test (oral lactose overload with monitoring of blood glucose and associated clinical manifestations). BMD was assessed by dual energy X-ray absorptiometry (DXA). As expected, physical activity score was higher in both groups for women classified as more active $(p>0.05)$. The BMD at hip and pelvis was lower in LI than in C group $(p<0.05)$. In addition, there was a tendency for a lower $B M D$ in $L 2, L 4$, femoral neck and total hip for $L I$ compared to $C$ group $(p<0.10)$. However, there was no main effect of physical activity level or interaction for the BMD at any other bone sites $(p<0.10)$. The $\mathrm{LI}$ group had lower $(\mathrm{p}<0.05)$ absolute free-fat mass, independently of physical activity level. Therefore, the results of the present study suggest that $\mathrm{LI}$ reduces BMD in pre-menopausal women and this reduction is independent of physical activity level.
\end{abstract}

KeYwords: Physical Exercise; Malabsorption; Lactose; Bone Mineral Density.

\section{Introduction}

The lactose intolerance (LI) is a gastrointestinal problem caused by the malabsorption of lactose by the intestinal cells $s^{1,2}$. The LI is present in three different forms: congenital, primary and secondary. The congenital form is extremely rare, and it is a disorder characterized by growth failure and infant diarrhea from the first exposure to mother's milk33. The primary form is an adult type and is the most common form, which is genetically determined ${ }^{2,3}$. The secondary form is caused by an injury in the intestine as a result of some gastrointestinal diseases ${ }^{3}$. In all cases there is a reduction in the activity of disaccharides enzymes, with the lactase being the most affected ${ }^{4}$.

The IL is characterized by clinical symptoms such as abdominal pain, diarrhea, flatulence, nausea and bloating after ingestion of milkderived foods ${ }^{5,6}$. This is caused by a reduction in the lactase enzyme quantity in the small intestine, so-called hypolactasia ${ }^{1,2}$. Accordingly, lactose cannot be fully hydrolyzed, which will instead be fermented by the intestinal bacterial flora ${ }^{1-3}$. Because of these symptoms aforementioned, the 
consumption of milk-derived foods are restricted in IL population ${ }^{3,5}$. In long term, IL can carry to a reduced ingestion of milk-derived products, which are rich in lactose. Therefore, the LI individuals will ingest and absorb less calcium ${ }^{1-3}$, predisposing those individuals to bone complications such as bone fracture as a consequence of a calciuminduced reduction in bone mineral content ${ }^{3,6,7}$. Accordingly, Obermayer-Pietsch et al. ${ }^{7}$, analyzed 73 postmenopausal women and found that women with CC genotype (lactase deficiency) reduced about $80 \%$ of their dairy calcium intake as well as the calcium absorption. The authors concluded that both insufficient calcium intake and reduced intestinal absorption can promote a reduction in bone mineral density (BMD) in women with IL, increasing therefore the risk of developing osteopenia and osteoporosis. A possible secondary effect, which was not reported in the literature yet, is that the low intake of milkderived products may affect protein intake, reducing therefore the free fat mass. In fact, milk is admittedly a food of great biological importance because it is an excellent source of protein, casein, BCAA and vitamin D. High intake of high biological proteins is essential for the maintenance and/or gain of muscle mass, which is the main component of fat-free mass ${ }^{8}$. Because women have a lower amount of lean mass, low protein intake may be more impactful in this population. A lower fat free mass may lead, in the long term, weight gain and increase in the body fat, once a higher fat-free mass has an impact on the basal energy expenditure and weight control ${ }^{9}$.

In fact, gender and age are the main risk factors linked to the loss of BMD. The risk of BMD loss is higher in females ${ }^{10,11}$. After the menopause, which occurs near 50 years old ${ }^{10}$, the rate of BMD loss accelerates the $1-1.5 \%$ per year to $3-4 \%$ per year, mostly because a reduction of estrogen production and a lower calcium absorption in the intestine ${ }^{12}$. However, any strategy attenuating the BMD loss in premenopausal phase could benefit the maintenance of a higher BDM at the beginning of the menopause. In this sense, regular practical of physical exercise has been described as an effective strategy to prevent reduction in bone tissue once sedentary individuals are more susceptive to loss $\mathrm{BMD}^{13}$. In the absence of large randomized controlled trials, the support of this affirmation comes from cross-sectional studies or short-term interventions, which have showed that physical activity practice is positively associated with BMD regardless gender and age $\mathrm{e}^{14,15}$. Among the tasks that could alter the BMD, the exercise activities able to generate mechanical stress and bone overload by compression, tension, torsion or shear are desirable. These mechanical actions create differences in electrical potential in the bone, acting as an electric field, leading to the deposition of minerals in the local stress ${ }^{15,16}$. Such studies suggest that activities with mechanical impact are protective against osteopenia and osteoporosis ${ }^{16-18}$. This is corroborated by Simkin et al. ${ }^{16}$, who conducted a short-term, 5-months interventional study with osteoporotic women, combining different exercises (load, comprehension and torsion) and found that trained group increased $3.8 \%$ of their BMD at forearm, while it reduced $1.5 \%$ in the control group. Heinonen et al. ${ }^{17}$ performing a 18-months, randomized study with high impact exercises in women (mean 39 years old) found larger increase in BMD at femoral neck in trained groups compared to the control. LoHMAN et al. ${ }^{18}$ found similar results in 34-yrs old women who performed strength training. The BMD at lumbar spine and femoral trochanter was significantly greater than in congener's control. The body areas with optimized response of BMD are lumbar spine $^{15,19,20}$ and femoral neck ${ }^{20,21}$.

To date, no studies investigating the relationship between regular physical activity and BMD in individuals with IL have been performed. These highlighted observations support the notion of an exercise-induced benefit on bone, but it is still unknown whether LI women physically active present a reversion, even partially, of the ILinduced reduction of BMD. The finding that the regular practice of physical exercise reverse or at least prevent the advance of LI-induced BMD loss would be important to propose a more efficient treatment to patients with LI, consequently improving their quality of life. Therefore, the aim of this study was to determine whether women with LI who have a higher level of physical activity would have proportionally higher BMD than their sedentary counterparts. A control group without LI was included to control the isolated effect of LI on BMD. The hypothesis of this study is that women with LI would have lower BMD than women without LI, but those with higher level of physical activity may have a higher DMO compared to those less active. 


\section{Method}

\section{Sample}

Sixty premenopausal women, who performed or not regular physical activity were enrolled in this study $(31.9 \pm 6.9$ years, $62.0 \pm 11.6 \mathrm{~kg}, 160.8 \pm 5.8 \mathrm{~cm})$, being 30 women with primary lactase intolerance (intolerant lactose group) and 30 control women without LI (C). Potential candidates to participate in the study who presented any chronic degenerative or transmissible diseases, or any other pathology that could alter BMD would be excluded. Participants were nonsmokers and had no other related diseases that could interfere with calcium absorption such as celiac disease or food allergy. Both LI and C groups were subdivided in less and more active, according to the International Physical Activity Questionnaire $\left(\right.$ IPAQ ${ }^{22}$. Thus, four groups were generated: LI more active, $\mathrm{LI}$ less active, $\mathrm{C}$ more active and $\mathrm{C}$ less active. They voluntarily participated in this study after reading and signing the free and informed consent. All procedures were previously approved by the Ethics Committee of the Federal University of Alagoas (CEP-UFAL).

\section{Experimental design}

This is a case-control, descriptive-comparative study. Firstly, body weight and height were measured. Then, the participants performed a lactose tolerance test to confirm the diagnosis of LI. Thereafter, they were scanned with dual-energy X-ray absorptiometry (DXA) to determine their BMD. Finally, they answered two questionnaires as an interview format: 1) general questionnaire to identify possible diseases and medication, 2) IPAQ ${ }^{22}$ questionnaire to identify their level of physical activity. All tests were performed at the same time of day.

\section{Anthropometric measurements}

Body mass was measured with a mechanical weighting scale (Filizola ${ }^{\circledR}$, anthropometric 31 , Sao Paulo, BRA) and height through a wall professional stadiometer (Physical, Terrazul ${ }^{\oplus}$, Sao Paulo, BRA).

\section{Lactose tolerance test}

The participants visited the laboratory in the morning after an 8- to 12-h overnight. After arriving at the laboratory, they ingested $50 \mathrm{~g}$ of liquid-form lactose and venous blood samples were collected at three moments: immediately before the intake of lactose (baseline), and 30 and 60 minutes after ingestion. Venous blood samples were immediately centrifuged at $3000 \mathrm{~g}$ for 10 minutes at $4^{\circ} \mathrm{C}$ to separate plasma. The plasma glucose concentration was measured by colorimetric reactions in spectrophotometer (Biotech kit, Varginha, Brazil). The lactose malabsorption diagnosis was assumed when plasma glucose increased less than $20 \mathrm{mg} / \mathrm{dl}^{3,23}$. The LI diagnosis was confirmed by combination of plasma glucose curve and the presence of symptoms such as diarrhea, constipation, headache, flatulence, distension and abdominal pain. The volunteers diagnosed with LI were allocated to the LI group. Those who do not show any of the symptoms and/ or alterations in plasma glucose curve described above were allocated in $\mathrm{C}$ group.

\section{Bone Mineral Density quantification}

Quantification of BMD was performed using a DXA equipment (Hologic QDR 2000; Hologic Inc, Walrtham, $\mathrm{MA}^{\oplus}$ ) that is considered the gold standard for measuring $\mathrm{BMD}^{24}$. The examination was performed with the participant lying in a supine position under a coupled stretcher equipment. Then, a metal rod moved over the individual sending X-ray waves from head to feet ${ }^{25}$. From the resistance encountered by the waves, bone mineral density, fat-free mass and fat mass were measured ${ }^{25}$. The bone areas analyzed were lumbar spine (L1-L4), femur, hip, pelvis and the whole body. A DXA trained staff performed all tests.

\section{International Physical Activity Questionnaire}

To estimate the weekly time spent in walking activities and moderate-to-vigorous physical activities, the Guidelines Protocol for Data Processing and Analysis of the IPAQ-long version was applied ${ }^{26}$. The participants reported the activities carried out during a typical week, with questions divided to activities at work, at home, transportation and leisure. The energy expended was expressed as MET-min/week. Energy expenditure was calculated separately for walking, moderate activities and vigorous activities, using the following formulas: 
Walking MET-min/week $=3.3 *$ walking minutes ${ }^{*}$ walking days $(1)$

Moderate MET-min $/$ week $=4.0 *$ moderate-intensity activity minutes $*$ moderate days $(2)$

Vigorous MET-min/week = $8.0 *$ vigorous-intensity activity minutes * vigorous-intensity days (3)

For walking was accounted the sum of walking activities at work, transport and leisure. For moderate and vigorous activity were accounted the sum of the activities considered moderate and vigorous, respectively, for labor, transportation, domestic engagements and leisure. Total energy expenditure for all activities was calculated by the following equation:

Total physical activity MET-min/week = sum of Walking + Moderate + Vigorous MET-min/week scores

Subsequently, the participants were classified as more or less active following these procedures: 1 ) the median of total weekly energy expenditure, expressed as MET-min/week was calculated for the total sample ( $\mathrm{n}=60) ; 2$ ) an average value corresponding to $1339 \mathrm{MET}$-min/week was found; 3) women located above the median were considered as more active, while women below the median as less active; 4) to avoid overlap between the groups ${ }^{19}$, women classified as border line around the median (10\% around the median) were excluded. The final sample into each group was: LI more active group $(\mathrm{n}=16)$, LI less active group $(\mathrm{n}=14), \mathrm{C}$ more active group $(\mathrm{n}=11)$ and $\mathrm{C}$ less active group $(\mathrm{n}=13)$. Thus, the LI group remained with 30 women in total, while the $\mathrm{C}$ group was reduced to 24 women.

\section{Results}

The four groups were similar for age (LI more active: $32.0 \pm 7.3$; $\mathrm{C}$ more active: $30.0 \pm 6.0$; LI less active: $31.2 \pm 8.1$ and $C$ less active: $33.5 \pm 8.1$ years, main effect of group and physical activity level $\mathrm{p}=0.94$ and 0.51 , respectively) and height $(160.3 \pm 6.4,158.9 \pm 10.6,161.4 \pm 7.1$ and $160.4 \pm 5.0$ $\mathrm{cm}$, main effect of group and physical activity level $\mathrm{p}=0.56$ and 0.54 , respectively). In addition, no main effect of group or level of physical activity for the total mass were found ( $\mathrm{p}=0.19$ and 0.21 , TABLE 1 ).

\section{Level of physical activity}

As expected, the more active groups (both LI and C) had higher energy expenditure for walking $(\mathrm{p}=0.01)$, and moderate $(\mathrm{p}=0.01)$ and vigorous $(\mathrm{p}=0.01)$ activities than their less active counterparts, which resulted in a -5 times larger

\section{Statistical analysis}

All analyzes were performed using SPSS (version 13.0, Chicago, USA). The variables were described as mean and standard deviation (SD). The normal distribution of the data was verified using the Kolmovorov-Smirnov test. The comparison of dependent variables between groups was performed using two-way ANOVA, having group (LI vs C) and physical activity level (more vs less active) as factors. An interaction between the factors was interpreted as a specific influence of physical activity level on the disease. The significance level was set at 5\% $(\mathrm{p}<0.05)$. Tendency to differences were interpreted when $\mathrm{p} \geq 0.05$ but $<0.10^{20}$.

$(\mathrm{p}=0.01)$ total weekly energy expenditure in the former (LI more active : 6691 \pm 2856 MET-min/ week; C more active: $7593 \pm 3032$ MET-min/week vs. LI less active: $1370 \pm 855 \mathrm{MET}-\mathrm{min} /$ week; C less active: $1327 \pm 733 \mathrm{MET}-\mathrm{min} /$ week).

\section{Body composition}

No main effect of group or level of physical activity for the total mass ( $\mathrm{p}=0.19$ and 0.21$)$, bone mineral content $(\mathrm{p}=0.52$ and 0.71$)$ and fat mass ( $\mathrm{p}=0.63$ and 0.27 ) were found (in both absolute and relative terms for these last two) (TABLE 1). However, there was a main group effect for the fatfree mass when expressed in absolute $(p=0.03)$, but not when expressed in relative terms $(\mathrm{p}=0.84)$. The absolute fat-free mass was significantly lower in LI than in C. 
TABLE 1 - Total body mass, bone mass, fat mass and fat-free mass in absolute and relative terms for control and lactose intolerance groups at different physical activity levels.

\begin{tabular}{lccccc}
\hline & \multicolumn{2}{c}{ Control group } & & \multicolumn{2}{c}{ Lactose intolerance group } \\
\cline { 2 - 3 } & Less active & More active & & Less active & More active \\
\hline Total body mass $(\mathrm{kg})$ & $59.26 \pm 11.07$ & $65.13 \pm 10.76$ & & $56.78 \pm 11.37$ & $59.09 \pm 13.23$ \\
\hline Bone mass $(\mathrm{kg})$ & $2.00 \pm 0.26$ & $2.06 \pm 0.23$ & & $1.97 \pm 0.24$ & $1.97 \pm 0.40$ \\
\hline Fat mass $(\mathrm{kg})$ & $18.95 \pm 5.32$ & $21.07 \pm 6.26$ & & $18.07 \pm 7.06$ & $20.14 \pm 8.12$ \\
\hline FFM $(\mathrm{kg})^{*}$ & $37.52 \pm 6.29$ & $41.11 \pm 5.81$ & & $35.80 \pm 4.66$ & $36.28 \pm 4.69$ \\
\hline Bone mass $(\%)$ & $3.46 \pm 0.43$ & $3.25 \pm 0.37$ & & $3.62 \pm 0.51$ & $3.44 \pm 0.62$ \\
\hline Fat mass $(\%)$ & $32.09 \pm 3.99$ & $32.27 \pm 4.99$ & & $31.19 \pm 6.80$ & $33.44 \pm 7.13$ \\
\hline FFM $(\%)$ & $64.43 \pm 3.83$ & $64.46 \pm 4.78$ & & $65.18 \pm 6.32$ & $63.10 \pm 6.64$ \\
\hline
\end{tabular}

\section{Quantification of bone mineral density per site}

There was no main effect of group $(\mathrm{p}=0.15-0.21)$, level of physical activity ( $p=0.46-0.95)$ or interaction ( $\mathrm{p}=0.40-0.95$ ) for DMO at lumbar spine L1, L3 and total, and femoral neck and total hip (TABLE 2). However, BMD at L2 ( $\mathrm{p}=0.08)$,
L4 $(\mathrm{p}=0.08)$ and femoral neck $(\mathrm{p}=0.07)$ tended to be lower in LI than in C (TABLE 2). Similarly, BMD at hip $(\mathrm{p}=0.01)$, total hip $(\mathrm{p}=0.07)$ and pelvis $(\mathrm{p}=0.04)$, but not at total pelvis $(\mathrm{p}=0.15)$, were lower in LI than in C (FIGURE 1). No effect of physical activity level $(\mathrm{p}=0.13-0.98)$ or interaction between physical activity and group $(\mathrm{p}=0.11-0.96)$ was found for these variables.

TABLE 2 - Bone mineral density at different sites in the control and lactose intolerance groups of different physical activity levels.

\begin{tabular}{lccccc}
\hline & \multicolumn{2}{c}{ Control group } & & \multicolumn{2}{c}{ Lactose intolerance group } \\
\cline { 2 - 3 } \cline { 6 - 6 } & Less active & More active & & Less active & More active \\
\hline BMD L1 $\left(\mathrm{g} / \mathrm{cm}^{2}\right)$ & $0.94 \pm 0.15$ & $0.99 \pm 0.13$ & & $0.91 \pm 0.80$ & $0.91 \pm 0.15$ \\
\hline BMD L2 $\left(\mathrm{g} / \mathrm{cm}^{2}\right) \dagger$ & $0.98 \pm 0.14$ & $1.12 \pm 0.23$ & & $0.97 \pm 0.09$ & $0.97 \pm 0.15$ \\
\hline BMD L3 $\left(\mathrm{g} / \mathrm{cm}^{2}\right)$ & $1.00 \pm 0.13$ & $1.05 \pm 0.15$ & & $0.97 \pm 0.09$ & $0.97 \pm 0.14$ \\
\hline BMD L4 $\left(\mathrm{g} / \mathrm{cm}^{2}\right) \dagger$ & $1.00 \pm 0.14$ & $1.05 \pm 0.12$ & & $0.98 \pm 0.11$ & $0.94 \pm 0.13$ \\
\hline BMD LT $\left(\mathrm{g} / \mathrm{cm}^{2}\right)$ & $0.98 \pm 0.14$ & $1.03 \pm 0.13$ & & $0.96 \pm 0.09$ & $0.95 \pm 0.13$ \\
\hline BMD nFR $\left(\mathrm{g} / \mathrm{cm}^{2}\right) \dagger$ & $0.91 \pm 0.11$ & $0.95 \pm 0.11$ & & $0.86 \pm 0.10$ & $0.88 \pm 0.12$ \\
\hline BMD FRT $\left(\mathrm{g} / \mathrm{cm}^{2}\right)$ & $1.17 \pm 0.21$ & $1.11 \pm 0.06$ & & $1.10 \pm 0.07$ & $1.08 \pm 0.12$ \\
\hline BMD TOTAL $\left(\mathrm{g} / \mathrm{cm}^{2}\right)$ & $1.11 \pm 0.07$ & $1.10 \pm 0.06$ & & $1.09 \pm 0.06$ & $1.08 \pm 0.11$ \\
\hline
\end{tabular}

BMD: body mineral density; L1-L4: lumbar spine 1 to 4 ; TL: total lumbar spine; nFR: femoral neck; FRT: total femoral. † Tendency to a main effect of group (Lactose intolerance lower than control, $p<0.10$ ). 

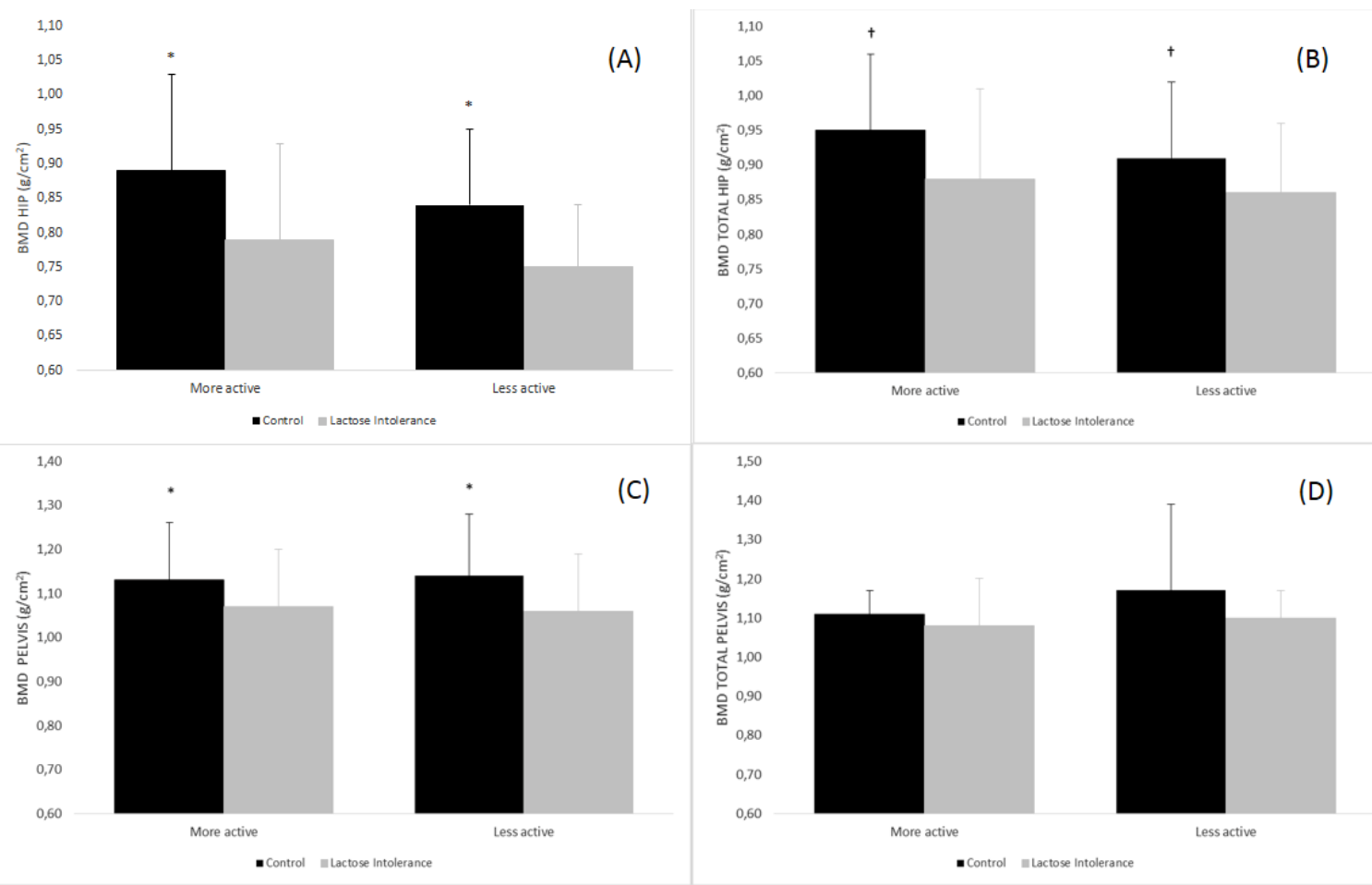

FIGURE 1 - Bone mineral density at hip (Panels A and B) and pelvis (panels C and D) in the control and lactose intolerance groups of different physical activity levels.

\section{Discussion}

In the present study, BMD of important sites such as femur, hip, pelvis and lumbar was lower in women with LI than in whose control. These LI women also had lower fat free mass than controls. However, there was no effect of the level of physical activity, suggesting that BMD was more affected by disease than by regular physical activity.

The BMD at hip and pelvis were significantly reduced ( $\sim-11$ and $-7.5 \%$, respectively) and there was a tendency for a decrease at L2, L4, femoral neck and the total hip (from -1 to -13\%) in women with LI compared to control. These results are in accordance with some studies that also found differences in the lumbar spine BMD and femoral neck between $\mathrm{C}$ and LI groups ${ }^{5,27-30}$. Di STEFANO et al. $^{5}$ showed an osteopenia incidence of $41 \%$ in the lumbar spine (L2-L4) and femoral neck in LI women. Obermayer-Pietsch et al. ${ }^{29}$ in a sample of 258 women in postmenopausal stage found significant reduction in the lumbar spine, femoral neck and hip to the LI group, corroborating earlier study by Honkanen et al. ${ }^{27}$ who also found reduced BMD for these same sites in LI Finnish women. There is a consensus that LI individuals with below-average BMD showed a reduction in calcium intake $e^{5,27,28,30-32}$. When the absorption of calcium, an essential micronutrient, is insufficient to replenish daily losses, calcium is removed from bones contributing to a negative balance of bone remodeling and may predispose individuals to osteopenia and osteoporose $e^{6,13,28}$. Unfortunately, calcium intake was not measured in this study, but in a previous study with a very similar population ${ }^{6}$, it was demonstrated that calcium intake in LI women was nearly three times lower compared to intake of the control women. This lower calcium intake in LI women must be by a reduction or even total abstinence in the consumption of milk-derived products.

Studies indicate that regular physical activity has a positive role in both the increase and maintenance of $\mathrm{BMD}^{15,33}$. Some studies have shown interesting results regarding the effect of long-term exercise on $\mathrm{BMD}^{17,33}$. Interestingly, the reduction in BMD in women with LI was independent of physical activity level, even with the active group presenting -5 times more weekly energy expenditure than their lesser active counterparts. It is hard to explain why physical activity has not had the expected impact on BMD, but it is worth noting that the less active group presented a weekly energy 
expenditure $-1300-1400 \mathrm{MET}-\mathrm{min} /$ week, which is much above the threshold of $600 \mathrm{MET}$-min/week for classification as moderately active following IPAQ, and even close to the threshold for classification as highly active (i.e., above $1500 \mathrm{MET}$-min/week) ${ }^{26}$. This suggests that the lack of difference between the groups may be because the less active group may already have a high level of physical activity. This fits well with the purposed dose-response curve of physical activity, in which the transition from sedentary to physically active is more impactful than the physically active to very active ${ }^{34}$. The fact the regular practice of physical activity was not effective to reverse the deleterious effects of LI women on BMD also suggests that changes in dietary habits, in particular reduced calcium intake, are more impactful on BMD than perform or not perform exercise regularly.

Even though, strong evidences indicate that physical activity is positively related to BMD, being an important factor in its maintenance ${ }^{15,35}$. This positive relationship can be explained by the pressure exerted on the bones by physical exercise favoring the bone remodeling $20,26,36$. However, not all forms of physical exercise lead to increase in BMD. Within the exercise modalities, those with beneficial potential are the activities that promote impact and lifting weight ${ }^{17,33}$ compared with those activities with no impact (e.g., water activities). The increase in BMD provided by these impact activities seem to be more pronounced in regions with larger cortical bone (e.g., femur), because they are metabolically more active and exposed to gravitational actions. However, not all forms of exercise lead to an increase in BMD. For example, HeInRICH et al..$^{37}$, comparing swimmers, runners, bodybuilders and inactive high school students, found that the order of beneficiaries in relation to BMD were primarily the bodybuilders followed by runners. The swimmers were disadvantaged. Similarly, in a randomized intervention study, BASSEY and RAMSDALE ${ }^{33}$ observed women engaged in a highimpact exercise program for 6 months increased their trochanter BMD by $3.4 \%$, compared with control women matched by age who underwent low-impact exercises. However, during the next following 6 months, the control group began to perform highimpact exercises and showed significant gains of $4.1 \%$ in the trochanter BMD. One possible explanation for lack of difference between more and less active women in the present study is that as the typo of physical activities were not controlled it was not possible to characterize the groups as doing exercises with high or low bone compression. Future interventional studies should propose exercises with bone comprehension to LI women in order to check the effectiveness of exercise in reversing bone deleterious process caused by the disease.

Finally, it was found in this study a reduction in fat-free mass in the LI group. Despite the lack of studies focused on the dietary profile of individuals with LI, most likely the reduction of fat-free mass may have been caused by a reduced consumption of milk-derived products, which are biologically valuable because they are whey protein, casein, BCAA and Vitamin D sources ${ }^{8}$. In accordance with the Institute OF Medicine ${ }^{38}$, it has been suggested a daily protein intake between 0.8 and $1.0 \mathrm{~g} . \mathrm{kg}^{-1}$ body weight. Although the food intake was not investigated in this study, which constitutes an important limitation, it is possible to speculate that a probable low intake of milk-derived protein was present in the LI group. A low protein intake, especially those of high biological value, may result in long term in a reduction of the muscle mass. This could explain why the fat-free mass was lower in the LI group than in the control group in the present study. Moreover, the reduction in carbohydrate intake arising from milk products, as cited in several studies ${ }^{19,21,22,26}$, may also contribute to the reduction in fat-free mass, since the low carbohydrate consumption promotes greater protein oxidation, reducing muscle mass.

This study has some limitations that deserve to be highlighted. Unfortunately, daily consumption of macro (especially proteins) and micronutrients (especially calcium, phosphorus and vitamin D) were not assessed. Therefore, it was not possible to know if a probable reduction in protein intake would be the primary cause of the lower fat-free mass observed in the LI group. Moreover, it was also not possible to determine whether a reduced calcium intake provoked a lower BMD in the LI group. However, similar studies appoint to this direction ${ }^{6}$. The results of the present study complement these findings and suggest that the regular practice of physical exercise alone is not able to reverse the deleterious effects of LI. Another important limitation is the level of physical activity was measured by IPAQ. This questionnaire evaluates the weekly energy expenditure, but does not inform whether the activities are of high or low impact. Future studies should evaluate if an intervention (longitudinal study) using exercise with impact is able to change BMD in LI women.

From the data presented, it can be concluded that the fat-free mass and BMD of important sites such as femur, hip, pelvis and lumbar are lower in 
women with LI than their control counterparts. These lower values were independent of the physical activity level, since even with a 5-time more weekly energy expenditure in the more active group, active
LI women presented similar reduction in BMD. These results suggest that the disease is a more powerful factor influencing BMD than the physical activity level.

\section{Acknowledgments}

The Laboratory UNILAB (Alagoas-Mangabeiras), Dra. Rosa Lina da Rocha Lima and Dr. Alex de Medeiros Lemos by running the blood tests. The SONOGRAF clinic (Alagoas-Mangabeiras) by performing DXA examination. For all women who took part of this study. The authors state that the support given to the development and completion of the research that resulted in the preparation of this article does not imply a conflict of interest between any of the parties.

\section{Resumo}

Influência da intolerância a lactose e do nível de atividade física sobre a densidade mineral óssea em mulheres jovens

0 objetivo desse trabalho foi verificar o efeito do nível de atividade física sobre a densidade mineral óssea (DMO) em mulheres intolerantes a lactose. Participaram do estudo sessenta mulheres pré-menopáusicas (idade: $31,9 \pm 6,9$ anos) separadas em dois grupos: 30 intolerantes a lactose (IL) e 30 controles saudáveis (C). Os grupos foram posteriormente subdivididos em menos e mais ativas a partir da mediana do gasto energético total semanal, estimado pelo questionário internacional de atividade física (IPAQ-versão longa). 0 diagnóstico de IL foi confirmado pelo teste de intolerância à lactose (sobrecarga oral de lactose com acompanhamento da curva glicêmica e manifestações clínicas associadas). A DMO foi avaliada pelo exame de absortometria de raio-X de dupla energia (DXA). Como esperado, o escore de atividade física foi maior para as mulheres classificadas como muito ativas em ambos os grupos $(p>0,05)$. A DMO do quadril e pelve foi menor para as mulheres do grupo IL que no grupo $C(p<0,05)$. Também houve uma tendência de menor DMO em $L 2$, $L 4$, colo do fêmur e quadril total no grupo IL comparado ao grupo $C(p<0,10)$. Contudo, não foi encontrado efeito principal do nível de atividade física ou interação entre os fatores para a DMO em nenhum desses sítios ósseos $(p>0,10)$. 0 grupo IL apresentou menor $(p<0,05)$ massa livre de gordura absoluta, o que foi independente do nivel de atividade física. Desta forma, os resultados sugerem que a IL reduz a DMO de mulheres pré-menopáusicas e que essa redução independe do nível de atividade física.

Palavras-chave: Exercício Físico; Má Absorção; Lactose; Conteúdo Mineral Ósseo.

\section{References}

1. Hovde O, Farup PG. A comparison of diagnostic tests of lactose malabsorption: which one is the best? BMC Gastroenterol. 2009;9:[7 p.].

2. Jellema P, Schellevis FG, Van Der Windt DA, Kneepkens CM, van der Horst HE. Lactose malabsorption and intolerance: a systematic review on the diagnostic value of gastrointestinal symptoms and self-reported milk intolerance. QJM. 2010;103(8):555-72.

3. Séva-Pereira A. Malabsorção de lactose do adulto em uma população brasileira [tese]. Campinas: Universidade Estadual de Campinas; 1981.

4. Lebenthal E, Lee PC. Possible alternate pathway for starch digestion in infants and mucosal glucoamylase activity in small intestinal atrophy (abstract). Pediatr Res. 1980;14:504. 
5. di Stefano M, Veneto G, Malservisi S, Cecchetti L, Minguzzi L, Strocchi A. Lactose malabsorption and intolerance and peak bone mass. Gastroenterology. 2002;122(7):1793-9.

6. Salomão NA, Silva TA, Geraldes AAR, Lima-Silva AE. Ingestão de cálcio e densidade mineral óssea em mulheres adultas intolerantes à lactose. Rev Nutr. 2012;25(5):587-95.

7. Obermayer-Pietsch MB, Gugatschka M, Reitter S, Plank W, Strele A, Walter D. Adult-type hypolactasia and calcium availability: decreased calcium intake or impaired calcium absorption? Osteoporos Int. 2007;18(4):445-51.

8. Swargerty DL, Walling AD, Klein RM. Lactose intolerance. Am Fam Physician. 2002;9(64):1845-50.

9. Lohamn, T. Body composition methodology in sports medicine. Phys Sports Med. 1982;10(12):46-58.

10. Cerqueira FS, Rezende LF. Atuação da fisioterapia na melhora da qualidade de vida da mulher no climatério e menopausa. Femina. 2002;30(7):477-9.

11. Riggs BL, Melton LJ. Involutional osteoporosis. N Engl J Med. 1986;314:676-86.

12. Plapler PG. Osteoporose e exercícios. Rev Hosp Clín Fac Med S Paulo. 1997;52(3):163-70.

13. Chilibeck PD, Sale DG, Webber CE. Exercise and bone mineral density. Sports Med. 1995;19(2):103-22.

14. Maïmoun L, Lumbroso S, Manetta J, Paris F, Leroux JL, Sultan C. Testosterone is significantly reduced in endurance athletes without impact on bone mineral density. Horm Res. 2003;59(6):285-92.

15. Kemmler W, von Stengel S, Weineck J, Lauber D, Kalender W, Engelke K. Exercise effects on menopausal risk factors of early postmenopausal women: 3-yr Erlangen fitness osteoporosis prevention study results. Med Sci Sports Exerc. 2005;37(2):194203.

16. Simkin A, Ayalon J, Leichter I. Increased trabecular bone density due to bone-loading exercises in postmenopausal osteoporotic women. Calcif Tissue Int. 1987;40(2):59-63.

17. Heinonen AP, Kannus H, Sievänen, POJA, Oja P, Pasanen M, Rinne M, et al. Randomized controlled trial of effect of highimpact exercise on selected risk factors for osteoporotic fractures. Lancet. 1996;348(9038):1343-7.

18. Lohman T, Going S, Pamenter R, Hall M, Boyden T, Houtkooper L, et al. Effects of resistance training on regional and total bone mineral density in premenopausal women: a randomized prospective study. J Bone Miner Res. 1995;10(7):1015-24.

19. Pruitt LA, Jackson RD, Bartels RL, Lehnhard HJ. Weight training effects on bone mineral density in early postmenopausal women. J Bone Miner Res. 1992;7(2):179-85.

20. Menkes A, Mazel S, Redmond R.A, et al. Strength training increases regional bone mineral density and bone remodeling in middle-aged and older men. J Appl Physiol. 1993;74(5):2478-84.

21. Ryan AS, Ivey FM, Hurlbut DE, Martel GF, Lemmer JT, Sorkin JD, et al. Regional bone mineral density after resistive training in young and older men and women. Scand J Med Sci Sports. 2004;14(1):16-23.

22. Pardini R, Matsudo SMM, Araújo T, Matsudo V, Andrade E, Braggion G, et al. Validação do Questionário Internacional de Nível de Atividade Física (IPAQ - Versão 6): estudo piloto em adultos jovens brasileiros. Rev Bras Ciên Mov. 2001;9(3):45-51.

23. Savaiano D. Lactose intolerance: an unnecessary risk for low bone density. Nestle Nutr Workshop Ser Pediatr Program. 2011;67:161-71.

24. World Health Organization. Assessment of fracture risk and its application to screening for postmenopausal osteoporosis: report of a WHO study group. World Health Organ Tech Rep Ser. 1994;843:1-129.

25. Fornetti WC, Pivarnik JM, Foley JM, Fiechtner JJ. Reliability and validity of body composition measures in female athletes. J Appl Physiol. 1999;87(3):1114-22.

26. International Physical Activity Questionnaire. Guidelines for data processing and analysis of the International Physical Activity Questionnaire (IPAC): short and long forms [Internet]. [localizaçáo desconhecida]: IPAC; 2005 [citado em 2018 mar 13 ]. Disponível em: <https://goo.gl/twjcpB>.

27. Honkanen R, Kröger H, Alhava E, Turpeinen P, Tuppurainen M, Saarikoski S. Lactose intolerance associated with fractures of weight-bearing bones in Finnish women aged 38-57 years. Bone. 1997;21(6):473-7.

28. Corazza GR, Benati G, di Sario A, Tarozzi C, Strocchi A, Passeri M, et al. Lactose intolerance and bone mass in postmenopausal Italian women. Br J Nutr. 1995;73(3):479-87.

29. Obermayer-Pietsch BM, Bonelli CM, Walter DE, et al. Genetic predisposition for adult lactose intolerance and relation to diet, bone density, and bone fractures. J Bone Miner Res. 2004;19(1):42-7.

30. Nieves JW, Golden AL, Sires E, Kelsey JL, Lindsay R. Teenage and current calcium intake are related to bone mineral density of the hip and forearm in women aged 30-39 years. Am J Epidemiol. 1995;141(4):342-51.

31. Kudlacek S, Freudenthaler O, Weissböerck H, Schneider B, Willvonseder R. Lactose intolerance: a risk factor for reduced bone mineral density and vertebral fractures? J Gastroenterol. 2002;37(12):1014-9. 
32. Suchy FJ, Brannon PM, Carpenter TO, Fernandez JR, Gilsanz V, Gould JB, et al. NIH consensus development conference statement: lactose intolerance and health. NIH Consens State Sci Statements. 2010; 27(2):1-27.

33. Bassey EJ, Ramsdale SJ. Increase in femoral bone density in young women following high-impact exercise. Osteoporos Int. $1994 ; 4(2): 72-5$.

34. Haskell WL, Lee IM, Pate RR, Powell KE, Blair SN, Franklin BA, et al. Physical activity and public health: updated recommendation for adults from the American College of Sports Medicine and the American Heart Association. Med Sci Sports Exerc. 2007;39(8):1423-34.

35. Heinonen A, Kannus P, Sievänen H, Pasanen M, Oja P, Vuori I. Good maintenance of high-impact activity-induced bone gain by voluntary, unsupervised exercises: an 8-month follow-up a randomized controlled trial. J Bone Miner Res. 1999;14(1):125-8.

36. Melton LJ, Atkinson EJ, O’ Fallon WM, Wahner HW, Riggs BL. Long-term fracture prediction by bone mineral assessed at different skeletal sites. J Bone Min Res. 1993;8(10):1227-33.

37. Heinrich CH; Going SB; Pamenter RW; Perry CD; Boyden TW; Lohman TG. Bone mineral content of cyclically menstruating female resistance and endurance trained athletes. Med Sci Sports Exerc. 1990;22(5):558-63.

38. Institute of Medicine. Dietary reference intakes for energy, carbohydrate, fiber, fat, fatty acids, cholesterol, protein, and amino acids. Washington: National Academy Press; 2005.

Adriano Eduardo Lima-Silva

Centro Acadêmico de Vitória

Departamento de Educação Física e Esporte da

Universidade Federal de Pernambuco

Rua Alto do Reservatório, s/n - Bela Vista

55608-68o - Vitória de Santo Antão - PE - BRAZIL. e-mail: limasilvaae@hotmail.com; adrianosilva@usp.br
Submitted: 01/03/2016

1st. Review: 26/04/2016

2nd. Review: 27/07/2016

Accepted: 26/09/2016 